\title{
The Effect Of Promotion, Price, And Quality Of Service On Customer Satisfaction Of PT. Aseng Keto Sukses Medan
}

\author{
Ricky Rafii Ritonga ${ }^{1}$, Christian Ardy ${ }^{2}$, Felix Giovanni Chandra ${ }^{3}$, Nicholas Geral Cendana ${ }^{4}$, Egon Sius Purba ${ }^{5}$ \\ 1,2,3,4,5 Management, Faculty of Economics, University of Prima Indonesia, \\ JL. Belanga No.1, Medan, 20118, Indonesia \\ ${ }^{*}$ Corresponding author: \\ Email: ricky.ritonga@gmail.com
}

\begin{abstract}
.
This research was motivated by a decrease in the number of customers of PT. Aseng Ketok Successful in 2020. The decrease in the number of customers indicates that the satisfaction of pt. Aseng Ketok Success Medan. By looking at the problems that exist, this research is directed to analyze how to increase satisfaction by supporting increased promotion, price, and, quality of service. In this study used is the criteria of permanent customers, which are meant by permanent customers here are service users who have more than twice used the services of PT. Aseng Ketok Success. The number of samples is determined based on calculations of the Slovin formula with a tolerable error rate of $5 \%$, then the sample count will be obtained as many as 150 people. The data analysis method used in this study is Multiple Regression, were previously tested the validity, reliability, and classical assumptions. The results showed that promotion, price, and quality of service have a positive and significant influence on customer satisfaction. The author's advice is to increase customer satisfaction can be done by improving promotions, maintaining customer satisfaction, and pricing more in line with customer capabilities. PT. Aseng Ketok Sukses Medan needs to maintain elements that have been considered good by customers and need to improve things that are still lacking.
\end{abstract}

Keywords: Promotion, Price, Quality Of Service, Satisfaction.

\section{INTRODUCTION}

The high rate of traffic accidents on the highway is proof that there are wide open business opportunities for workshop services, especially car repair shops. So that over time business people in the field of workshop services are increasingly mushrooming, with various prices and facilities they have, which will provide choices for consumers in using the services of the workshop. Companies need to build a proper customer satisfaction strategy so that the level of complaints gets smaller [1]. Customer satisfaction will change over time [2]. The sense of satisfaction experienced by customers will certainly contribute to the internal parties of an organization. This can be seen from the number of complaints felt by customers or suggestions and criticisms that make the organization's input material in determining strategies in facing the world of competition [3]. Promotion is the spearhead of a product's business activities to reach the target market and sell the product. It is almost certain that promotions can be carried out for promotions both in the form of goods and services and both branded and unbranded [4]. Promotion is carried out through various sources, namely billboard advertisements, visits to schools, distribution of brochures to advertisements in print and electronic fields [5]. Promotion through the use of social media, especially Facebook and Instagram, should be carried out by certain departments. In this regard, existing customers are only based on an emotional approach among existing employees. For new prospective customers, especially those who have just started shipping goods from Bandung to Batam, of course, it is very difficult to get a source of information about goods transportation services. Considering these new customers do 
not have a choice between freight forwarding services. Furthermore, from the social media users, it is stated what facilities new consumers will get at the price offered.

This information is needed by every consumer who wants to carry out their business activities [6]. As a consumer who gets various stimuli for the product or service he sees, it will certainly be important information if in the future [7]. Expensive prices do not become lazy as long as it is of good quality. This shows that consumers will not question the high price [8]. So we need the right strategy for the company to determine the right price for the response of competitors' prices [1]. The price indicators can be measured such as prices according to product quality, competitive prices, and affordable prices [7].Service has a very close relationship with customer satisfaction, namely encouraging customers to undergo a strong relationship with the company. In the long term, this kind of bond allows the company to understand carefully consumer expectations and customer needs [9]. Services are all economic activities with outputs other than products in a physical sense, consumed and produced at the same time, providing added value and in principle intangible to the first buyer [10]. Service quality continues to be the company's concern in improving consumer purchasing decisions [3]. It takes a strong commitment to maintaining good service to its customers [11]. Employees must provide extensive knowledge to consumers. Sales promotion girl/boy provides knowledge that can help consumers to make purchasing decisions, for example by providing information about products [9] To increase customer satisfaction, the Aseng Ketok workshop also provides a guarantee for car repair services carried out by the Aseng Ketok car repair shop. To get more customers, Aseng Ketok car repair shops set competitive prices, so that they are still able to attract customers from certain individuals and institutions. Based on the above, it is interesting to conduct a study on the effect of service quality, price, and customer satisfaction on customer loyalty.

\section{METHODS}

This research will be conducted at PT Aseng Ketok Sukses Medan, which is located at Jalan Tuamang NO 2B. The research time starts from May 2020 - October 2020. The generalization area consists of objects/subjects that have certain qualities and characteristics determined by the researchers to be studied and then conclusions are drawn. The population in this study were shop consumers at PT Aseng Ketok Sukses as many as 150 people. The collection technique can be done in several ways, such as questionnaires, surveys, observation methods, and documentation methods.

\section{RESULT AND DISCUSSION}

\section{The Effect of Promotion on Consumer Satisfaction}

The results of the final test of the promotion variable obtained $2.858>1.994$ at a significant value of $0.006<0.05$, which gives the result that promotion has a positive and significant impact on customer satisfaction. The results of this study are in line with the results of previous research conducted by [12][13][14] which states that promotion has a positive and significant effect on customer satisfaction. The implications of the findings indicate that goals such as behavior modification, informing, persuading, reminding customers. After the promotion is held, it is expected that there will be purchases from customers and high satisfaction. Purchasing is the end of the communication process. Buyers also have a high attachment to the products they consume. Promotion is a marketing activity that aims to influence customers or potential customers so that these customers or potential customers want to buy or use the services offered.

\section{The Effect of Price on Consumer Satisfaction}

The results of data analysis show that the price obtained is $3.450>1.994$, at a significant value of 0.001 $<0.05$, it gives the result that the price has a positive and significant impact on customer satisfaction. The study supports the results of previous studies which state that price has a positive and significant effect on customer satisfaction [15][16][17]. The implications of the findings indicate that it is necessary to understand the psychological aspects of pricing, for example, consumers are highly dependent on price as an indicator of 
consumer satisfaction in buying a product. Consumers have the perception that at the moment they have no other indication of product quality and price. Whereas price perception can also be influenced by store reputation, advertising, and other variables.

\section{The Effect of Service Quality on Consumer Satisfaction}

Based on the data analysis proves that the service quality variable obtained 4.043>1.994 at a significant value of $0.000<0.05$, thus giving the result that service quality has a positive and significant impact on customer satisfaction. The results of this study support the results of the study [18] [19] [20] which states that service quality affects customer satisfaction. The implications of the findings indicate that in providing quality services and meeting the level of consumer interest to achieve customer satisfaction. Services are provided as actions or actions of a person or organization to provide satisfaction to customers or customers. These actions can be done by directly serving customers or placing something where the customer already knows the place or service by telephone.

\section{CONCLUSION}

The results show that promotion, price, and service quality have a positive and significant effect on customer satisfaction at PT Aseng Ketok Sukses. The most dominant variable or has the greatest influence in influencing customer satisfaction is the quality of service obtained by the customer.

\section{REFERENCES}

[1] A. F. Nasib, Konsep Intisari Strategi pemasaran. Jawa Tengah: CV. Pena Persada, 2019.

[2] I. L. N. R. K. C. H. Martin, "The Role of Customer Satisfaction in Mediating the Relationship Between Service Quality and Price on Customer Loyalty," Enrich. J. Manag., vol. 12, no. 1, pp. 400-411, 2021.

[3] Nasib, "Pengaruh Kualitas Pelayanan Terhadap Kepuasan Pelanggan (Studi Kasus Pada Kola Renan Bengawan Solo Pangkalan Brandan),” J. Ilm. Manaj. Bisnis, vol. 18, no. 1, pp. 30-44, 2017.

[4] N. R. A. I. Lestari, Dasar Pemasaran. Yogyakarta: Deepublish, 2019.

[5] N. S. Chaniago, "Pengaruh Bauran Promosi Dan Lokasi Terhadap Keputusan Kuliah Pada Politeknik Unggul LP3M," JIPI, vol. 2, no. 1, pp. 38-50, 2018.

[6] S. Nasib, "Maksimalisasi Peningkatan Kepuasan Pelanggan Pada PT. Lautan Abadi Pratama Melalui Promosi Dan Kualitas Pelayanan Pada PT. Lautan Abadi Pratama,” Ekon. Bisnis, vol. 27, no. 1, pp. 550-561, 2021.

[7] Nasib, "Optimalisasi Personal Selling, Lokasi Dan Harga Dalam Meningkatkan Keputusan Mengikuti Program Kepemilikan Rumah KPR Tipe 36,” J. Mantik Penusa, vol. 3, no. 1, pp. 14-20, 2019.

[8] N. R. Amelia, "Pengaruh Kualitas Pelayanan, Harga Dan Citra Kampus Terhadap Loyalitas Mahasiswa Mengikuti Program MGM (Member Get Member) Melalui Kepuasan Mahasiswa Sebagai Variabel Intervening," Abdi Ilmu, vol. 1, no. 1, pp. 121-133, 2018.

[9] N. Herwan Nafil, “Optimalisasi Kepuasan Pelayanan Dan Komunikasi Pada Supermarket Mr. Ben Medan,” Juranl Ekon. Dan Kebijak. Publik, vol. 4, no. 2, pp. 111-118, 2019.

[10] Daryanto, Sari Kuliah Manajemen Pemasaran. Bandung: PT Sarana Tutorial Nurani Sejahtera Bandung, 2012.

[11] N. S. M. Z. R. Daulay, Konsep Kualitas Pelayanan, Harga Dan Citra Kampus Dan Loyalitas Mahasiswa Sebuah Kajian Teoritis Dan Analisis. Surabaya: Global Aksara Pres, 2021.

[12] R. J. A. M. I. Haanurat, "The Influence of Product Quality and Promotion on Customer Satisfaction and Its Impact on Customer Loyalty PT. Mahakarya Sejahtera Indonesia," Proceeding 3rd Int. Conf. Accounting, Bus. Econ., vol. 1, no. 4, pp. 1491-1498, 2019.

[13] J. D. Sunarsi, "The Influence of Product Mix, Promotion Mix and Brand Image on Consumer Purchasing Decisions of Sari Roti Products in South Tangerang," PINISI Discret. Rev., vol. 1, no. 1, pp. 165-174, 2020.

[14] Y. G. W. R. H. W. N. Qomariah, "Impact of Price, Product Quality, and Promotion on Consumer Satisfaction in Cosmetics and Skincare,” J. Econ. Finance. Manag. Stud., vol. 04, no. 07, pp. 978-986, 2021.

[15] A. H. Permana, "Price and Customer Satisfaction on Loyalty: An Empirical Study of Online Transportation in Indonesia," Int. J. Innov. Sci. Res. Technol., vol. 5, no. 3, pp. 1275-1280, 2020.

[16] A. J. S. D. Djumarno, "Effect Of Price And Service Quality On Customer Satisfaction And Its Implications For 
Customer Loyalty At Aston Pluit Hotel \& Residence Jakarta," Dinasti Int. J. Econ. Finance. Account., vol. 2, no. 1, pp. 77-91, 2021.

[17] K. H. W. M. M. M. P. K. A. C. Sukartiko, "The Effect of Perceived Quality, Price, and Product Safety on Loyalty Consumer XYZ Products," Agroindustrial J., vol. 6, no. 2, pp. 423-431, 2019.

[18] T. G. Y. Yi, “The Effect Of Service Quality On Customer Satisfaction, Loyalty, And Happiness In Five Asian Countries," Psychol Mark, pp. 1-16, 2018.

[19] B. A. F. U. A. Y. A.-B. D. Singh, "Impact of Service Quality on Customer Loyalty and Customer Satisfaction in Islamic Banks in the Sultanate of Oman," Orig. Res. Impact, vol. April-June, pp. 1-10, 2020.

[20] P.-L. H. B. C. Y. L. C.-C. Chen, "The Influence Of Service Quality On Customer Satisfaction And Loyalty In B2B Technology Service Industry,” Total Qual. Manag. Bus. Excell., vol. 30, no. 13-14, pp. 1449-1465, 2019. 